\title{
15. MAGNETIC PROPERTIES AND INCOMPATIBLE ELEMENT GEOCHEMISTRY OF SOME IGNEOUS ROCKS FROM DEEP SEA DRILLING PROJECT LEG 641
}

\author{
Surendra P. Verma,${ }^{2}$ Instituto de Geofísica, Universidad Nacional Autonóma de México, \\ Ciudad Universitaria, México 20 D.F., México
}

\section{INTRODUCTION}

I received five unoriented samples of igneous rocks from four Sites of Leg 64 of the Deep Sea Drilling Project (DSDP). I have measured several magnetic properties, alkalis $(\mathrm{K}, \mathrm{Rb}$, and $\mathrm{Cs})$, alkaline-earth ( $\mathrm{Ba}$ and $\mathrm{Sr}$ ) element concentrations, and ${ }^{87} \mathrm{Sr} /{ }^{86} \mathrm{Sr}$ ratios of these samples. This study reports the results.

\section{MAGNETIC PROPERTIES}

The experimental method is described by Verma and Banerjee (in press). All magnetic measurements were taken at the rock magnetism laboratory, University of Minnesota. Tables 1 and 2 present these results.

Natural remanent magnetization (NRM) intensity $\left(J_{\mathrm{n}}\right)$ varies from 0.374 to $10.6 \times 10^{-3} \mathrm{emu} \cdot \mathrm{cm}^{-3}$. Corresponding anhysteritic remanent magnetization (ARM) intensity $\left(J_{\mathrm{a}}\right)$ ranges from 0.498 to $11.0 \times 10^{-3} \mathrm{emu}$. $\mathrm{cm}^{-3}$. Thus, $J_{n}$ and $J_{a}$ show somewhat similar ranges of variation. Dolerites from Site 478 possessing lower $J_{n}$ values are more altered than the other samples. Viscous remanent magnetization (VRM) acquisition experiments conducted for about $30,000 \mathrm{~min}$. show rather small but measurable VRM components. The VRM growth curves consist of two or three distinct segments of generally increasing slopes. Such growth curves have been obtained by other investigators in other sites (Lowrie, 1974; Kent and Lowrie, 1977; Verma and Banerjee, in press). Least-square fitting of the data permits their extrapolation for $10^{5} \mathrm{~min}$. $\left(J_{\text {vex }}\right)$. The results show that these younger dolerites are considerably less viscous than the diabases (dolerites) from Leg 63 (Verma and Banerjee, in press). The gabbro from Hole 481A shows a VRM acquisition similar to the dolerites in the present study.

I tested the stabilities of the three magnetizations (NRM, ARM, and VRM) by stepwise alternating field (AF) demagnetization. Figure 1 shows the demagnetization curves. The ARM and NRM show similar demagnetization curves, especially for the latter three samples. But the VRM consistently shows much lower stability. Thus, a large part of the NRM in these rocks may be the original thermal remanent magnetization (TRM) component, and VRM may not be a serious problem for these samples.

The weak-field susceptibility $(\chi)$ of these samples ranges from 11 to $31 \times 10^{-3} \mathrm{emu}\left(\mathrm{cm}^{-3} \cdot \mathrm{Oe}^{-1}\right)$. The

\footnotetext{
${ }^{1}$ Curray, J. R., Moore, D. G., et al., Init. Repts. DSDP, 64: Washington (U.S. Govt. Printing Office).

2 Earlier publications of the author are under the name of Surendra Pal.
}

Koenigsberger ratio $\left(Q_{n}\right)$ ranges from 0.039 to 1.0 and is much lower than the average $Q_{n}(=7.92)$ reported by Lowrie (1974) for a large number of DSDP basalts. But the present values are within the range of variation observed for the diabases of Leg 63 (Verma and Banerjee, in press). Thus, the induced magnetization component seems to be important for the dolerite and gabbro.

The saturation magnetization $\left(\mathrm{M}_{s}\right)$ shows a narrow range of 0.38 to $1.0 \mathrm{emu} / \mathrm{g}$, but saturation remanent magnetization $\left(\mathrm{M}_{r}\right)$ varies from 0.031 to $0.21 \mathrm{emu} / \mathrm{g}$ and shows a greater variation than $\mathbf{M}_{s}$. The $\mathrm{M}_{r} / \mathrm{M}_{s}$ ratio implies multidomain (MD) grains for the dolerite in Sample 478-53-3, 13-16 cm and pseudosingle domain (PSD) grains for the other samples. Figure 2 shows a plot of $\mathrm{M}_{r} / \mathrm{M}_{s}$ versus $\mathrm{H}_{c r} / \mathrm{H}_{c}$. Our samples fall near the field of diabases of Leg 63 (Verma and Banerjee, in press), and in fact they extend this field considerably but still seem to be distinguishable from the field of basalts of Leg 63.

The thermomagnetic properties are summarized in Table 2 and Figure 3 shows the thermomagnetic curves. The dolerites show reversible or slightly irreversible curves, whereas the gabbro shows an irreversible thermomagnetic curve. The Curie temperature $\left(\mathrm{T}_{c}\right)$ ranges from 147 to $508^{\circ} \mathrm{C}$. We can infer, based on the low $\mathrm{T}_{c}$ of $147^{\circ} \mathrm{C}$, that the dolerite in Sample $477 \mathrm{~A}-2-2,8-10 \mathrm{~cm}$ contains titanomagnetites with a very low degree of oxidation. The dolerites from Hole 478 show reversible (or slightly irreversible) $\mathrm{M}_{s}$-versus- $\mathrm{T}$ curves and considerably higher $T_{c}\left(\sim 500^{\circ} \mathrm{C}\right)$. They seem to document earlier observations by Hall and Ryall (1977) and Verma and Banerjee (in press). Following Hall and Ryall (1977), we might attribute such high $T_{c}$ to high-temperature initial cooling oxidation causing the original titanomagnetites to split into magnetite and ilmenite (magnetite causing the high $\mathrm{T}_{c}$ ). The gabbro from Hole 481A (Sample $481 \mathrm{~A}-15-4,18-20 \mathrm{~cm})$ also show a high $\mathrm{T}_{c}\left(\sim 509^{\circ} \mathrm{C}\right.$; heating cycle), but upon cooling they show a concave curve with the lowest well-defined $\mathrm{T}_{c}\left(\sim 186^{\circ} \mathrm{C}\right.$; cooling cycle). Upon reheating, the concave curve persists, but, curiously, the minimum $T_{c}$ increases to $\sim 215^{\circ} \mathrm{C}$.

\section{GEOCHEMISTRY}

The experimental method is given in Verma (in press). All geochemical measurements (Table 3) were conducted at the Graduate School of Oceanography, University of Rhode Island. The average values of "normal" ridge basalts are also included for comparison. The concentration of trace elements varies considerably. Dolerites show altered mesostasis by clay 
Table 1. Magnetization characteristics of Leg 64 igneous rocks.

\begin{tabular}{|c|c|c|c|c|c|c|c|c|c|c|c|c|c|c|c|}
\hline Sample & Rock Type & $J_{n}$ & $J_{a}$ & $J_{v}$ & $J_{\text {vex }}$ & $\mathrm{MDF}_{n}$ & $\mathrm{MDF}_{a}$ & $\mathrm{MDF}_{v}$ & $J_{a} / J_{n}$ & $J_{v e x} / J_{n}$ & $\mathrm{MDF}_{a} / \mathrm{MDF}_{n}$ & $\mathrm{MDF}_{v} / \mathrm{MDF}_{n}$ & $x$ & $Q_{n}^{\prime}$ & $Q_{n}$ \\
\hline $474 \mathrm{~A}-43-2,75-77 \mathrm{~cm}$ & dolerite & 10.6 & $\begin{array}{l}10.9^{b} \\
11.1^{b}\end{array}$ & $\begin{array}{c}1.96 \\
(30,000)\end{array}$ & 2.4 & 56 & 36 & 7.6 & 1.0 & 0.2 & 0.6 & 0.1 & 31 & 0.34 & 0.76 \\
\hline $477 \mathrm{~A}-2-2,8-10 \mathrm{~cm}$ & dolerite & 9.27 & 3.81 & $\begin{array}{c}0.495 \\
(30,000)\end{array}$ & 0.65 & 91 & 40 & 8.7 & 0.4 & 0.1 & 0.4 & 0.1 & 20 & 0.46 & 1.0 \\
\hline $478-41-1,71-73 \mathrm{~cm}$ & dolerite & $0.374^{\mathrm{a}}$ & 0.498 & $\begin{array}{c}0.023 \\
(30,400)\end{array}$ & 0.032 & 234 & 245 & 48 & 1.3 & 0.1 & 1.0 & 0.2 & 11 & 0.034 & 0.076 \\
\hline $478-53-3,13-16 \mathrm{~cm}$ & dolerite & 0.458 & 0.771 & $\begin{array}{c}0.085 \\
(30,000)\end{array}$ & 0.11 & 72 & 56 & 8.4 & 1.7 & 0.2 & 0.8 & 0.1 & 26 & 0.018 & 0.039 \\
\hline $481 \mathrm{~A}-15-4,18-20 \mathrm{~cm}$ & gabbro & $2.62^{\mathrm{a}}$ & 2.15 & $\begin{array}{c}0.345 \\
(30,000)\end{array}$ & 0.47 & 336 & 339 & 46 & 0.8 & 0.2 & 1.0 & 0.1 & 16 & 0.16 & 0.36 \\
\hline
\end{tabular}

Note: $J_{n}$ is intensity of NRM in $10^{-3} \mathrm{emu} \cdot \mathrm{cm}^{-3} ; J_{a}$ is intensity of ARM in $10^{-3} \mathrm{emu} \cdot \mathrm{cm}^{-3} ; J_{v}$ is intensity of VRM acquired on demagnetized state in $10^{-3}$ emu $\cdot \mathrm{cm}^{-3}$ (time of acquisition is given underneath in parenthesis, in min.): $J_{\text {vex }}$ is intensity of VRM extrapolated for $10^{5}$ min.; MDF $_{n}$ is median destructive field for NRM in Oe; MDF me $_{a}$ is median destructive field for ARM in Oe; $\mathrm{MDF}_{y}$ is median destructive field for VRM in Oe; $\chi$ is weak field susceptibility in $10^{-3}$ emu $\mathrm{cm}^{-3} ; Q_{n}^{\prime}$ is the modified Koenigsberger ratio, $J_{n} / \chi ; Q_{n}$ is the Koenigsberger ratio, $J_{n} / 0.45 \chi$.

a This NRM intensity $\left(J_{n}\right)$ has been corrected for a small antiparallel magnetic component.

b Duplicate measurements.
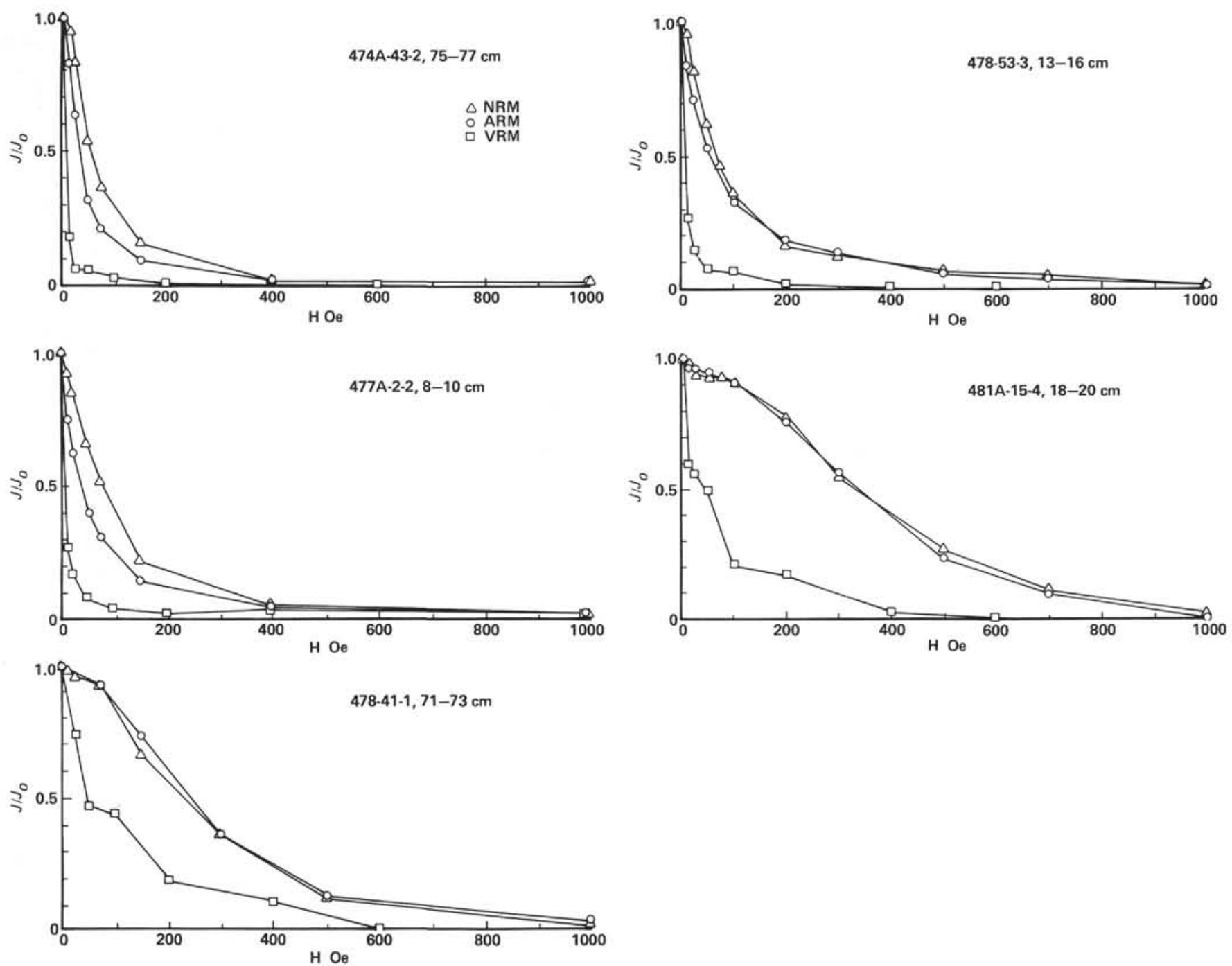

Figure 1. Stepwise AF demagnetization curves of NRM, ARM, and VRM for Leg 64 igneous rocks. 


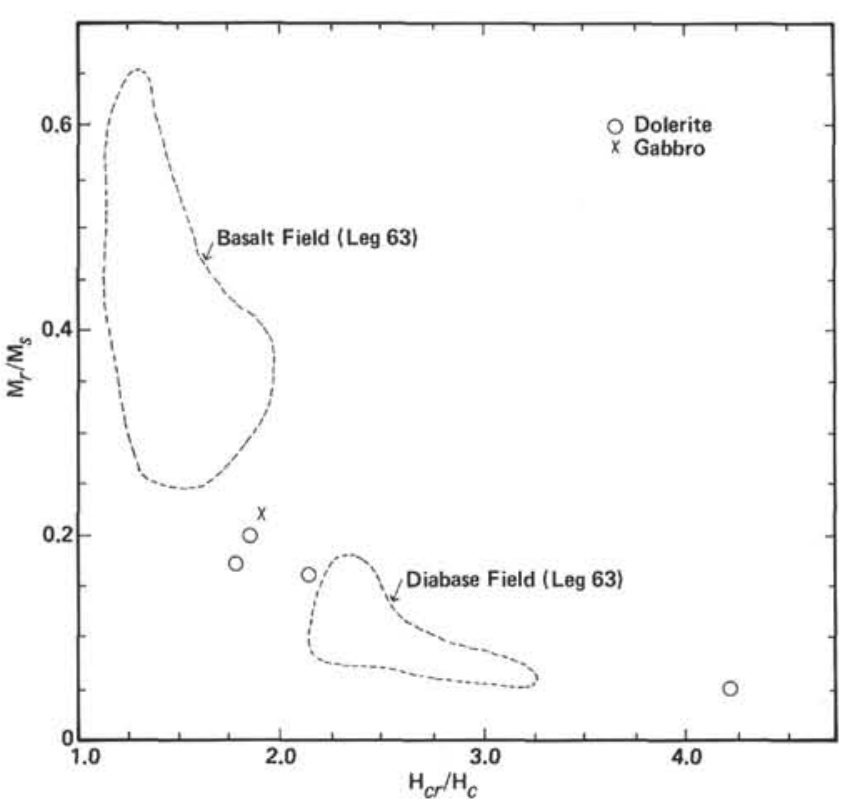

Figure 2. Plot of $\mathrm{M}_{r} / \mathrm{M}_{s}$ against $\mathrm{H}_{c r} / \mathrm{H}_{c}$. (Basalt and diabase [dolerite] fields of Leg 63 rocks are also given for comparison.)

minerals and veins altered by zeolites. This is particularly significant for the dolerites from Hole 478. But the gabbro from Hole 481A seems to be less altered than the dolerites.

Potassium, rubidium, and cesium are highly susceptible to seawater alteration; $\mathrm{Ba}$ and $\mathrm{Sr}$ are affected to a lesser degree (Hart, 1969; Hart et al., 1974). Large changes in $\mathrm{Ba}$ concentrations have also been observed at other DSDP sites (Rice et al., 1979; Verma, in press), but differences in $\mathrm{Sr}$ concentrations (of almost a factor of two) are not caused entirely by alteration. There seem to be prealteration differences in the trace elements of these rocks, perhaps related in large part to fractional crystallization. Most element ratios are similar to those found in normal ridge basalts, although significant differences exist for $\mathrm{K} / \mathrm{Cs}$ and $\mathrm{Rb} / \mathrm{Cs}$ ratios-perhaps because of seawater alteration. But dredged rocks from the Gulf of California also show rather low K/Cs and $\mathrm{Rb} / \mathrm{Cs}$ ratios (López et al., 1978; Verma, unpublished).

The whole-rock ${ }^{87} \mathrm{Sr} /{ }^{86} \mathrm{Sr}$ ratio varies from 0.70256 \pm 5 to $0.70293 \pm 3$. As ${ }^{87} \mathrm{Sr} /{ }^{86} \mathrm{Sr}$ is also susceptible to seawater alteration, this ratio and the $\mathrm{Sr}$ content are also measured on the leached samples (residues from acid leaching) to determine whether any of this variation in ${ }^{87} \mathrm{Sr} / 86 \mathrm{Sr}$ is "primary." The method for leaching is described in Verma (in press).

The ${ }^{87} \mathrm{Sr} /{ }^{86} \mathrm{Sr}$ of dolerites from Holes $474 \mathrm{~A}$ and $477 \mathrm{~A}$ decreased slightly. The ratio on leached gabbro is significantly higher than the ratio for the two dolerites. The gabbro ${ }^{87} \mathrm{Sr} /{ }^{86} \mathrm{Sr}$ ratio is similar to the ratio for one dolerite from Hole 478 (Sample 478-41-1, 71-73 cm). This dolerite shows no decrease in ${ }^{87} \mathrm{Sr} /{ }^{86} \mathrm{Sr}$ ratio after leaching. The other dolerite from this hole (Sample 478-53-3, 13-16 cm) shows an even higher ${ }^{87} \mathrm{Sr} /{ }^{86} \mathrm{Sr}$ ratio in the leached sample (although the error in this measurement is rather large and could not be improved after repeating the run), implying perhaps that the leached sample is left with significantly more altered phases than the whole rock. After leaching, the dolerites from Hole 478 show a greater weight loss than the other three samples.

The ${ }^{87} \mathrm{Sr} /{ }^{86} \mathrm{Sr}$ ratio on leached samples varies from $0.70240 \pm 4$ to $0.70280 \pm 6$ (omitting the anomalously high ratio obtained for Sample 478-53-3, 13-16 cm). With only a few analyses at hand, it is not possible to attribute any spatial significance to these isotopic differences. But the variation in prealteration ${ }^{87} \mathrm{Sr} /{ }^{86} \mathrm{Sr}$ is within the range reported for normal ridge basalts (White and Schilling, 1978). Lopez et al. (1978) and Terrell et al. (1979) studied major and trace element geochemistry of rocks dredged from the Gulf of California and reached a similar conclusion: The samples are normal ridge basalts.

\section{SUMMARY}

The younger and less-altered dolerite and gabbro are less viscous than the older and more altered diabases from Leg 63 . The rocks from Leg 64 show a wide range

Table 2. Hysteresis and thermomagnetic characteristics of Leg 64 igneous rocks.

\begin{tabular}{|c|c|c|c|c|c|c|c|c|c|c|c|}
\hline Sample & $\mathrm{M}_{\mathrm{S}}$ & $\mathrm{M}_{r}$ & $\mathrm{M}_{r} / \mathrm{M}_{S}$ & $\mathrm{H}_{c}$ & $\mathrm{H}_{c r}$ & $\mathrm{H}_{c r} / \mathrm{H}_{c}$ & $x_{i}$ & $\chi_{p}$ & $x_{i} / x_{p}$ & $\mathrm{~T}_{c}$ & Remarks \\
\hline \multirow[t]{2}{*}{$474 \mathrm{~A}-43-2,75-77 \mathrm{~cm}$} & 1.0 & 0.17 & 0.17 & 48 & 79 & 1.6 & 3.6 & 1.3 & 277 & 262 & h.c. Reversible \\
\hline & 0.98 & 0.18 & 0.18 & 51 & 80 & 1.6 & 3.4 & 1.3 & 262 & & $\begin{array}{l}\text { c.c. Heated to } 280^{\circ} \mathrm{C} \text { at } 5^{\circ} \mathrm{C} / \mathrm{min} \text {. (reheated to } 560^{\circ} \mathrm{C} \text {; } \\
\text { still reversible) }\end{array}$ \\
\hline \multirow[t]{3}{*}{$477 \mathrm{~A}-2-2,8-10 \mathrm{~cm}$} & 0.38 & 0.061 & 0.16 & 56 & 128 & 2.3 & 1.1 & 0.86 & 128 & 147 & h.c. Reversible(?) \\
\hline & $(0.38)$ & $(0.060)$ & $(0.16)$ & (59) & (133) & $(2.3)$ & $(1.0)$ & $(0.83)$ & (120) & & (h.c.; reproducibility test) \\
\hline & 0.40 & 0.057 & 0.14 & 44 & 98 & 2.2 & 1.3 & 0.66 & 197 & & c.c. Heated to $530^{\circ} \mathrm{C}$ at $2.5^{\circ} \mathrm{C} / \mathrm{min}$. \\
\hline \multirow{2}{*}{$478-41-1,71-73 \mathrm{~cm}$} & 0.61 & 0.12 & 0.20 & 196 & 341 & 1.7 & 0.63 & 1.3 & 48 & 508 & h.c. Reversible(?) \\
\hline & 0.56 & 0.073 & 0.13 & 96 & 180 & 1.9 & 0.76 & 1.1 & 69 & & c.c. Heated to $550^{\circ} \mathrm{C}$ at $10^{\circ} \mathrm{C} / \mathrm{min}$. \\
\hline \multirow[t]{2}{*}{$478-53-3,13-16 \mathrm{~cm}$} & 0.62 & 0.031 & 0.05 & 39 & 170 & 4.4 & 0.78 & 1.1 & 71 & 491 & h.c. Reversible(?) \\
\hline & 0.58 & 0.037 & 0.06 & 46 & 155 & 3.4 & 0.80 & 1.0 & 80 & & c.c. Heated to $550^{\circ} \mathrm{C}$ at $10^{\circ} \mathrm{C} / \mathrm{min}$. \\
\hline \multirow[t]{2}{*}{$481 \mathrm{~A}-15-4,18-20 \mathrm{~cm}$} & 0.95 & 0.21 & 0.22 & 141 & 253 & 1.8 & 1.5 & 0.83 & 181 & 509 & h.c. Irreversible \\
\hline & 0.72 & 0.12 & 0.17 & 72 & 183 & 2.5 & 1.7 & 0.90 & 189 & 186 & $\begin{array}{l}\text { c.c. Heated to } 600^{\circ} \mathrm{C} \text { at } 5^{\circ} \mathrm{C} / \mathrm{min} \text {.; concave cooling curve; } \\
\text { reheated: concave curve persists, but } \mathrm{T}_{c} \cong 215^{\circ} \mathrm{C}\end{array}$ \\
\hline
\end{tabular}

Note: $\mathrm{M}_{S}$ is saturation magnetization in emu $\bullet \mathrm{g}^{-1} ; \mathrm{M}_{r}$ is saturation remanent magnetization in emu $\cdot \mathrm{g}^{-1} ; \mathrm{H}_{c}$ is coercive force in Oe; $\mathrm{H}_{c r}$ is remanent coercive force in $\mathrm{Oe} ; x_{i}$ is strong field initial susceptibility $\left(\mathrm{M}_{r} / \mathrm{H}_{c}\right)$ in $10^{-3} \mathrm{emu} \cdot \mathrm{g}^{-1} \mathrm{Oe}^{-1} ; x_{\mathrm{p}}$ is strong field ; susceptibility (mean slope of saturation curve) in $10^{-5}$ emu $\cdot \mathrm{g}^{-1}$ $\mathrm{Oe}^{-1} ; \mathrm{T}_{c}$ is Curie temperature in ${ }^{\circ} \mathrm{C} ; \mathrm{h} . \mathrm{c}$. is heating cycle; c.c. is cooling cycle. The first row (h. c.) of hysteresis data pertains to the unheated (original) sample. The second row (c.c.) of data corresponds to the sample heated to obtain thermomagnetic curves. For Sample 477A-2-2, 8-10 cm, the first two rows of data pertain to unheated samples and show the reproducibility of measurements. 

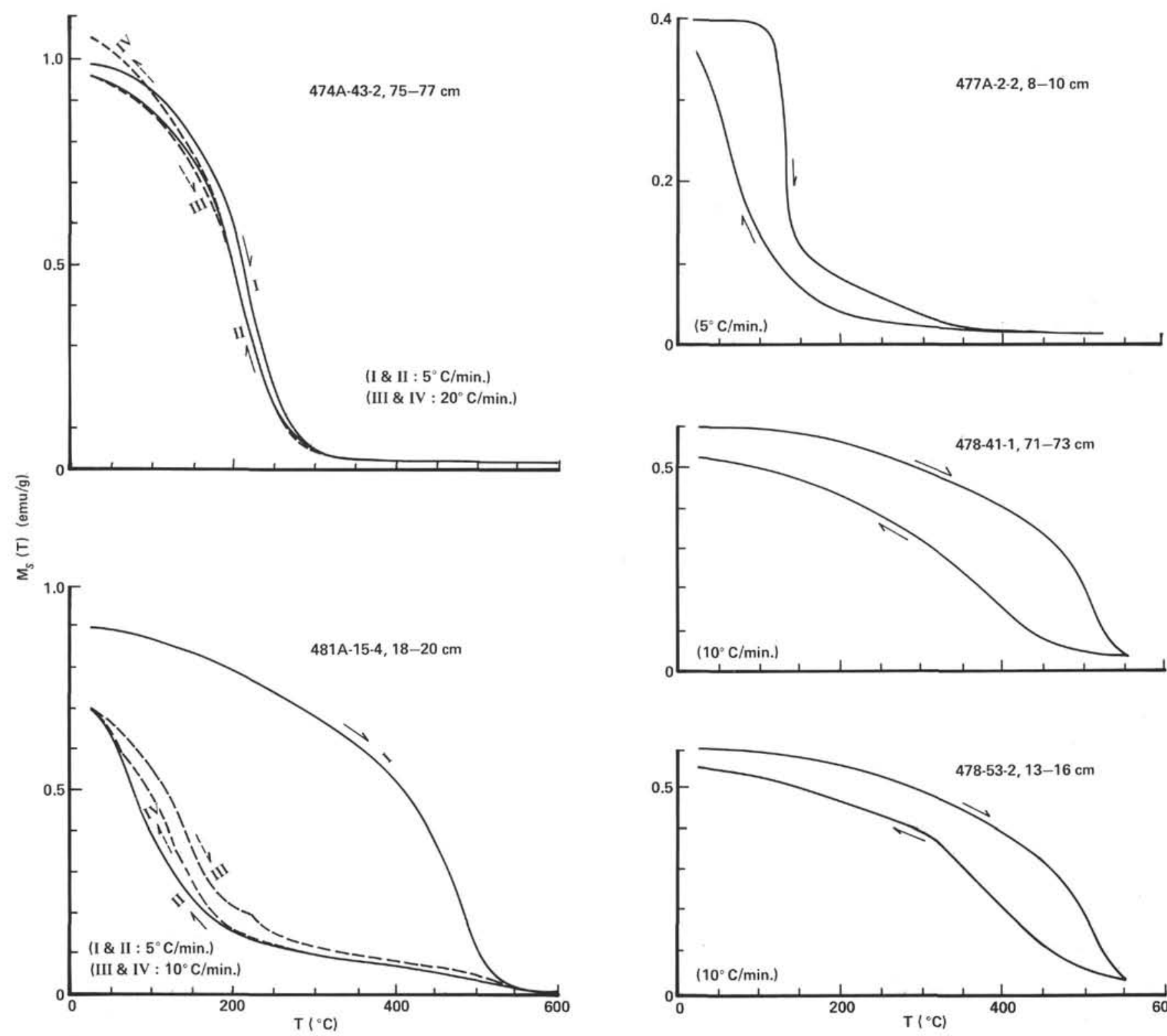

(I \& II : $5^{\circ} \mathrm{C} / \mathrm{min}$.)

III \& IV $: 20^{\circ} \mathrm{C} / \mathrm{min}$.)

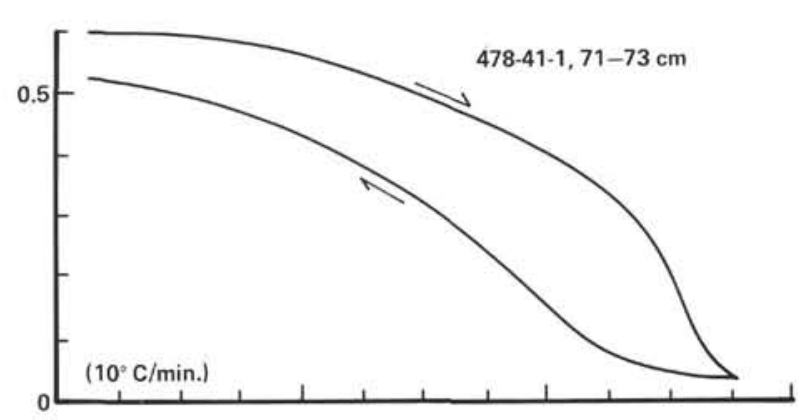

Figure 3. Thermomagnetic curves for Leg 64 igneous rocks. (Heating and cooling cycles are indicated by arrows; $\rightarrow$ and $\leftarrow$, respectively.) Heating and cooling rates are given in parentheses. Reheating and recooling curves are shown with dashed lines.

of Curie temperature $\left(147-508^{\circ} \mathrm{C}\right)$, and their trace elements differ considerably. The ${ }^{87} \mathrm{Sr} / 86 \mathrm{Sr}$ ratio for leached samples shows a wide range (0.7024-0.7028), and these values seem to be primary (prealteration). But the ratios are comparable to those obtained for normal ridge basalts, suggesting that the source of the igneous rocks from the Gulf of California and the normal ridge basalts is similar.

\section{ACKNOWLEDGMENTS}

I am grateful to the shipboard scientists on DSDP Leg 64 for making the samples available and to S. K. Banerjee and J.-G. Schilling for experimental facilities and helpful comments. This work was supported partly by the University of Minnesota through V. Rama Murthy and partly by the National Science Foundation under grant OCE78-24690. I also thank D. V. Kent and S. S. S. Iyer for reading the manuscript.

\section{REFERENCES}

Hall, J. M., and Ryall, P. J. C., 1977. Rock magnetism of basement rocks, Leg 37. In Aumento, F., Melson, W. G., et al., Init. Repts. DSDP, 37: Washington (U.S. Govt. Printing Office), 489-501.

Hart, S. R., 1969. K, Rb, Cs contents and K/Rb, K/Cs ratios of fresh and altered submarine basalts. Earth Planet. Sci. Lett., 6:295-303.

1976. LIL element geochemistry, Leg 34 basalts. In Hart, S. R., Yeats, R. S., et al., Init. Repts. DSDP, 34: Washington (U.S. Govt. Printing Office), 283-288.

Hart, S. R., Erlank, A. J., and Kable, E. J. D., 1974. Sea floor basalt alteration: some chemical and $\mathrm{Sr}$ isotopic effects. Contrib. Mineral. Petrol., 44:219-230.

Kent, D. V., and Lowrie, W., 1977. VRM studies in Leg 37 igneous rocks. In Aumento, F., Melson, W. G., et al., Init. Repts. DSDP, 37: Washington (U.S. Govt. Printing Office), 525-529.

López, M. M., Pérez, R. J., Urrutia, F. J., et al., 1978. Geochemistry and petrology of some volcanic rocks dredged from the Gulf of California. Geochem. J., 12:127-132. 
Lowrie, W., 1974. Oceanic Basalt magnetic properties and the Vine and Matthews hypothesis. J. Geophys., 40:513-536.

Rice, S., Langmuir, C. H., Bender, J. F., et al., 1979. Basalt from Deep Sea Drilling Project Holes 417A and 417D, fractionated melts of a light rare-earth depleted source. In Donnelly, T., Franchetau, J., Bryan, W., Robinson, P., Flower, M., Salisbury, M., et al., Init. Repts. DSDP, 51, 52, 53, Pt. 2: Washington (U.S. Govt. Printing Office), 1099-1111.

Staudigel, H., Frey, F. A., and Hart, S. R., 1979. Incompatible traceelement geochemistry and ${ }^{87} / 86 \mathrm{Sr}$ in basalts and corresponding glasses and palagonites. In Donnelly, T., Franchetau, J., Bryan, W., Robinson, P., Flower, M., Salisbury, M., et al., Init. Repts. DSDP, 51, 52, 53, Pt. 2: Washington (U.S. Govt. Printing Office), $1137-1144$.
Terrell, D. J., Pal, S., López, M. M., et al., 1979. Rare earth elements in basalt samples, Gulf of California. Chem. Geol., 26:267-275.

Verma, S. P., in press. $\mathrm{K}, \mathrm{Rb}, \mathrm{Cs}, \mathrm{Ba}$, and $\mathrm{Sr}$ isotope ratios of igneous rocks from Deep Sea Drilling Project Leg 63. In Haq, B., Yeats, R., et al., Init. Repts. DSDP, 63: Washington (U.S. Govt. Printing Office).

Verma, S. P., and Banerjee, S. K., in press. Magnetic properties of igneous rocks from Deep Sea Drilling Project Leg 63. In Haq, B., Yeats, R., et al., Init. Repts. DSDP, 63: Washington (U.S. Govt. Printing Office).

White, W. M., and Schilling, J.-G., 1978. The nature and origin of geochemical variation in Mid-Atlantic ridge basalts from the Central North Atlantic. Geochim. Cosmochim. Acta, 42:1501-1516.

Table 3. Geochemical characteristics of samples of Leg 64 igneous rocks.

\begin{tabular}{|c|c|c|c|c|c|c|c|}
\hline & $\begin{array}{c}474 \mathrm{~A}-43-2,75-77 \mathrm{~cm} \\
\text { Dolerite }\end{array}$ & $\begin{array}{c}477 \mathrm{~A}-2-2,8-10 \mathrm{~cm} \\
\text { Dolerite }\end{array}$ & $\begin{array}{c}478-41-1,71-73 \mathrm{~cm} \\
\text { Dolerite }\end{array}$ & $\begin{array}{c}478-53-3,13-16 \mathrm{~cm} \\
\text { Dolerite }\end{array}$ & $\begin{array}{c}481 \mathrm{~A}-15-4,18-20 \mathrm{~cm} \\
\text { Gabbro }\end{array}$ & "Normal" $\mathrm{F}$ & Ridge Basalts ${ }^{\mathrm{e}}$ \\
\hline $\mathrm{K}^{\mathrm{a}}$ & $804 \pm 4$ & $1560 \pm 10$ & $1506 \pm 9$ & $3820 \pm 25$ & $3160 \pm 20$ & 1064 & 732 \\
\hline $\mathrm{Rb}^{\mathrm{a}}$ & $1.20 \pm 0.01$ & $1.30 \pm 0.01$ & $1.95 \pm 0.02$ & $4.16 \pm 0.04$ & $5.09 \pm 0.04$ & 1.02 & 0.75 \\
\hline $\mathrm{Cs}^{\mathrm{a}}$ & $0.17 \pm 0.02$ & $0.36 \pm 0.05$ & $0.33 \pm 0.05$ & $0.55 \pm 0.06$ & $0.15 \pm 0.01$ & 0.0131 & 0.009 \\
\hline $\mathrm{Ba}^{\mathrm{a}}$ & $13.4 \pm 0.1$ & $21.4 \pm 0.2$ & $39.2 \pm 0.4$ & $64.7 \pm 0.6$ & $83.3 \pm 0.5$ & 12.2 & 6.2 \\
\hline $\mathrm{Sr}^{\mathrm{a}}$ & $121.7 \pm 0.3$ & $234.4 \pm 0.6$ & $208.5 \pm 0.5$ & $222.0 \pm 0.6$ & - & 124 & 92 \\
\hline${ }^{87} \mathrm{Sr} / 86 \mathrm{Sr}^{\mathrm{b}}$ & $0.70259 \pm 5$ & $0.70256 \pm 5$ & $0.70276 \pm 4$ & $0.70293 \pm 3$ & - & 0.70265 & - \\
\hline $\mathrm{Rb} / \mathrm{Sr}^{\mathrm{c}}$ & $0.00986 \pm 9$ & $0.00555 \pm 4$ & $0.00935 \pm 10$ & $0.0187 \pm 2$ & - & 0.0082 & 0.0082 \\
\hline $\mathrm{K} / \mathrm{Sr}$ & $6.61 \pm 0.04$ & $6.66 \pm 0.05$ & $7.22 \pm 0.05$ & $17.2 \pm 0.1$ & - & 8.58 & 7.96 \\
\hline $\mathrm{K} / \mathrm{Rb}$ & $670 \pm 7$ & $1200 \pm 12$ & $772 \pm 9$ & $918 \pm 11$ & $621 \pm 6$ & 1043 & 976 \\
\hline $\mathrm{K} / \mathrm{Cs}$ & $4700 \pm 600$ & $4300 \pm 600$ & $4600 \pm 700$ & $6900 \pm 800$ & $21100 \pm 1400$ & 81200 & 81300 \\
\hline $\mathrm{K} / \mathrm{Ba}$ & $60.0 \pm 0.5$ & $72.9 \pm 0.8$ & $38.4 \pm 0.5$ & $59.0 \pm 0.7$ & $37.9 \pm 0.3$ & 87 & 118 \\
\hline $\mathrm{Sr} / \mathrm{Ba}$ & $9.1 \pm 0.1$ & $11.0 \pm 0.1$ & $5.3 \pm 0.1$ & $3.4 \pm 0.1$ & - & 10.2 & 14.8 \\
\hline $\mathrm{Rb} / \mathrm{Cs}$ & $7.1 \pm 0.8$ & $3.6 \pm 0.5$ & $5.9 \pm 0.8$ & $7.6 \pm 0.8$ & $34 \pm 2$ & 78 & 83 \\
\hline $\begin{array}{l}\text { Weight loss on } \\
\text { leaching }(\%)\end{array}$ & 32.5 & 32.7 & 37.7 & 38.3 & 29.4 & & \\
\hline $\begin{array}{l}\mathrm{Sr}^{\mathrm{a}} \\
\text { (leached sample) }\end{array}$ & $40.8 \pm 0.2$ & $77.5 \pm 0.3$ & $59.3 \pm 0.2$ & $65.2 \pm 0.3$ & $89.8 \pm 0.4$ & & \\
\hline $\begin{array}{l}{ }^{87} \mathrm{Sr} / 86 \mathrm{Sr}^{\mathrm{b}} \\
\text { (leached sample) }\end{array}$ & $0.70240 \pm 4$ & $0,70252 \pm 5$ & $0.70280 \pm 6$ & $0.70341 \pm 14$ & $0.70279 \pm 7$ & & \\
\hline $\mathrm{Sr}$ l.s./Sr w.r. ${ }^{\prime}$ & 0.34 & 0.33 & 0.28 & 0.29 & - & & \\
\hline
\end{tabular}

a All concentrations are in $\mu \mathrm{g} \cdot \mathrm{g}^{-1}$ (ppm).

b The ${ }^{87} \mathrm{Sr} / 86 \mathrm{Sr}$ ratios are normalized to ${ }^{86} \mathrm{Sr} / 88 \mathrm{Sr}=0.11940$ and adjusted to SRM $987{ }^{87} \mathrm{Sr} / 86 \mathrm{Sr}$ ratio of 0.71021 . The measured ratio for the SRM 987 standard is $0.71028_{2} \pm 42(2 \sigma, n=19)$ during the period of about one year. In this period, the Eimer and Amend $\mathrm{SrCO}_{3}$ standard gave a value of $0.708071_{1} \pm 34(2 \sigma, n=$ 9). The errors reported on individual ${ }^{87} \mathrm{Sr} / 86 \mathrm{Sr}$ ratios are two times the standard error of the mean $\left(2 \sigma_{\epsilon}\right)$ multiplied by $10^{5}$.

c The quoted errors are the analytical errors multiplied by $10^{5}$.

$\mathrm{d}_{\mathrm{Sr}}$ l.s./Sr w.r. = Sr concentration in leached sample/Sr concentration in whole rock.

e First column: Average MORB values for trace elements and ${ }^{87} \mathrm{Sr} / 86 \mathrm{Sr}$ ratio are Hart's (1976) as cited in Staudigel et al. (1979). The element ratios are calculated from the trace element data. Second column: average of all normal ridge basalts given by White and Schilling (1978). The ratios are calculated from the trace element data. 